Florida International University

FIU Digital Commons

7-1-2020

\title{
Spiritual Activism and Political Solidarity in So Far From God and Mother Tongue: Two Views By Two Authors
}

Jean Paul Russo

Florida International University, jruss004@fiu.edu

Follow this and additional works at: https://digitalcommons.fiu.edu/etd

Part of the American Literature Commons, Chicana/o Studies Commons, Latin American History Commons, Latina/o Studies Commons, Literature in English, North America Commons, and the Women's Studies Commons

\section{Recommended Citation}

Russo, Jean Paul, "Spiritual Activism and Political Solidarity in So Far From God and Mother Tongue: Two Views By Two Authors" (2020). FIU Electronic Theses and Dissertations. 4461.

https://digitalcommons.fiu.edu/etd/4461

This work is brought to you for free and open access by the University Graduate School at FIU Digital Commons. It has been accepted for inclusion in FIU Electronic Theses and Dissertations by an authorized administrator of FIU Digital Commons. For more information, please contact dcc@fiu.edu. 
FLORIDA INTERNATIONAL UNIVERSITY

Miami, Florida

\title{
SPIRITUAL ACTIVISM AND POLITICAL SOLIDARITY IN SO FAR FROM GOD AND \\ MOTHER TONGUE: TWO VIEWS BY TWO
}

AUTHORS

\author{
A thesis submitted in partial fulfillment of \\ the requirements for the degree of \\ MASTER OF ARTS \\ in \\ ENGLISH \\ by \\ Jean Paul Russo
}

2020 
To: Dean Michael R. Heithaus

College of Arts, Sciences and Education

This thesis, written by Jean Paul Russo, and entitled Spiritual Activism and Political Solidarity in So Far From God and Mother Tongue: Two Views By Two Authors, having been approved in respect to style and intellectual content, is referred to you for judgment.

We have read this thesis and recommend that it be approved.

Anna Luszczynska

Michael Grafals

Anne Castro, Major Professor

Date of Defense: July 1, 2020

The thesis of Jean Paul Russo is approved.

Dean Michael R. Heithaus

College of Arts, Sciences and Education

Andrés G. Gil

Vice President for Research and Economic Development and Dean of the University Graduate School 
ABSTRACT OF THE THESIS

SPIRITUAL ACTIVISM AND POLITICAL SOLIDARITY IN SO FAR FROM GOD AND MOTHER TONGUE: TWO VIEWS BY TWO AUTHORS

\author{
by \\ Jean Paul Russo \\ Florida International University, 2020 \\ Miami, Florida \\ Professor Anne Castro, Major Professor
}

This thesis focuses on the intersection between spirituality and political action in the works of two Latinx authors, Demetria Martinez and Ana Castillo. Building on Gloria Anzaldua's theories of trauma, narrative, and what she terms 'conocimiento,' I contend that the novels So Far From God, and Mother Tongue, present an alternative approach to political action that is derived from a common experience of suffering and trauma as experienced by Latina communities. The political actions in the two novels and the ideas which inspire those actions, are born out of a need for solidarity between individuals, and are founded upon the idea that politics ought to be inspired by the spiritual lives and beliefs of individuals, as it is a central aspect of their identity. 
CHAPTER 1

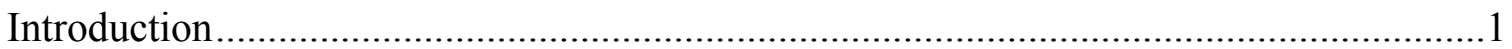

Section 1 Ana Castillo's So Far From God ..................................................................

Part 1: Solidarity Through Shared Spiritual Experience.........................................4

Part 2: Healing the Wound: Trauma, Healing, and Identity Formation ...................9

Part 3: Spiritual Activism: Politics Inspired by Faith ..........................................14

$\begin{array}{lr}\text { CHAPTER 2 } & 19\end{array}$

Section 1 Demetria Martinez's Mother Tongue …………….........................................19

Part 1: Hybrid Spirituality: Mary's Evolving Spiritual Identity ...........................20

Part 2: Narrative As a Healing Practice ...............................................................24

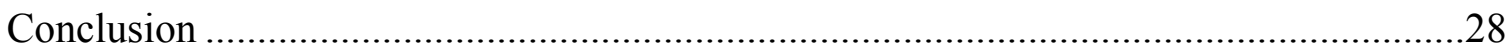

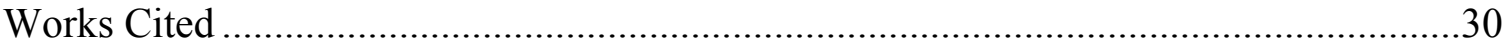


Spiritual Activism and Political Solidarity in So Far From God and Mother Tongue: Two Views By Two Authors

Spirituality and religion hold a prominent role in LatinX literature. ${ }^{1}$ The spiritual beliefs and practices within LatinX communities are often a means through which these communities are able to comprehend and make meaning of their lived experiences.

Through the exploration of spiritual and religious knowledge which many LatinX communities have incorporated into their communal, and ethnic identities, they are able to relate and connect with one another despite national, gender, and economic differences. Although there has been a historical shift towards a scientific, and secular mode of thought as being the more accurate way of interpreting reality, there is a growing and renewed interest in how spiritual beliefs are able to resist dominant European models of thinking which have in effect worked to elevate the status - and knowledge - of certain groups of people while invalidating the knowledge and truths of others (517, The Sacred). Within the growing volume of LatinX literature, Latina authors are increasingly exploring how spiritual beliefs and practices are vital towards inspiring alternative modes of political thought and social activism that contends for the rights, representation and liberation of marginalized communities.

While issues concerning race, gender, and social inequality are prominent within LatinX literature, there is also a strong focus on how religion informs the way that the aforementioned issues are discussed, understood and interpreted. As academia and the scientific fields have moved further away from acknowledging the importance of

\footnotetext{
${ }^{1}$ Gustavo Perez Firmat in discussing what LatinX literature teaches non-latino readers about Latino culture describes: "And what does Latino literature teach? For the most part, what readers already know, or think they know, about Latinos, Latinas, and Latin Americans: That they are... somewhat mysterious, very sensuous, and definitely spiritual" (Tongue Ties 140)
} 
religious traditions and knowledge to the development of societal structures, the field of LatinX literature is continuing to produce discourse which takes these phenomena into account as it questions how our modern political systems have been inspired by traditional religious thought. In Activism and the American Novel: Religion and Resistance in Fiction by Women of Color, Channette Romero examines a series of books written by women of color that use spiritually inspired politics and relations to advocate for social justice. Romero explains that "the growing inclusion of women of color's religions and spirituality in their fiction, and their link to political activism, has not yet been fully examined, both because of the newness of this emerging literature and because of the limitations of our scholarly approaches"(19). Due to enlightenment-era, and scientifically inspired approaches to constructing modes of understanding reality and knowledge, there are limitations to modern scholarly traditions which include the process of invalidating other forms of knowledge that have been beneficial for pre-colonial, and non-European societies in the past ${ }^{2}$.

While Channette Romero discusses various areas of literary and religious studies concerning the spiritually-inspired literature of Women of color, my thesis focuses on a specific facet of what Romero calls women's resistance literature. Romero explores writing by women of color from both African American backgrounds and Latin American backgrounds. In contrast, I focus on the writings of three women within the

\footnotetext{
${ }^{2}$ Gloria Anzaldua describes a shift from rational and scientific based knowledge to a system of understanding which is based on spiritual, and mythic ways of knowing. She states: "Many are witnessing a major cultural shift in their understanding of what knowledge consists of and how we come to know , a shift from the kinds of knowledge valued now to the kinds that will be desired in the twenty-first century, a shift away from knowledge contributing both to military and corporate technologies and to the colonization of our lives..., to the inner exploration of the meaning and purpose of life. You attribute this shift to the feminization of knowledge, one beyond the subject-object divide, a way of knowing and acting on ese saber you call 'conocimiento.' Skeptical of reason and rationality, conocimiento questions conventional knowledge's current categories, classifications, and contents."(119)
} 
LatinX field of literary studies: Gloria Anzaldua's spiritual philosophy in Light in the Dark: Rewriting Identity, Spirituality, Reality, Ana Castillo's novel So Far From God, and Demetria Martinez's novel Mother Tongue. I approach these LatinX texts in an effort to highlight the importance of creating alternative forms of political thought and social action that are based not solely on the physical, and tangible aspects of the lived experiences of lower economic communities, but on the belief systems which create alternative political movements which defy, and resist, the already established political systems that are currently in place. Building on Gloria Anzaldua's theories of the place of trauma, and the wound, towards producing spiritual awareness (what she calls conocimiento), I focus on how So Far From God and Mother Tongue envision and create political ideologies and movements which grow out of the need for solidarity between individuals within their immediate communities. The political thought and practice that is developed in these texts are similarly inspired and informed by shared experiences of inward psychological and spiritual healing, and by faith that leads to social action.

The two novels have different ways of developing their political ideologies. So Far From God makes a more explicit connection between the spiritual experiences of its characters as being central to their political thought, while Mother Tongue looks at the evolution of its main character from a New Age, politically disconnected spiritual practitioner, to someone who is more grounded, and informed, in the politics of her community and who is able to develop a spiritual philosophy which empowers her political endeavors. As a result, Martinez's and Castillo's novels engage in a religious studies scholarship about the place of the sacred, and religion, in both politics and in what Channette Romero calls Resistance Literature. In doing so, these two novels not only 
question long-standing traditional forms of knowledge, but they also question how long traditions of historical authorization of sacred texts have in themselves been oppressive towards certain groups of people. These novels ultimately attempt to place themselves as alternative sacred texts for modern times.

\section{Section 1 Ana Castillo's So Far From God}

\section{Part 1: Solidarity Through Shared Spiritual Experience}

So Far From God traces the spiritual experiences of three daughters to explore various forms of relating religious and supernatural practices with politics. Such religious experiences are composed of heightened spiritual awareness, a miraculous healing occurrence which is symbolic of inward and community healing, and a faith-based

political theory. The novel puts forth a political vision that represents the needs and values of women who have previously been overlooked, and oppressed by a capitalist political system. Three ways in which the characters in So Far From God bring about their vision of spiritually inspired politics into reality is through solidarity between groups of people who have previously been at odds with one another, by incorporating healing experiences into the center of a political theory and practice, and by creating socio-political organizations that are inspired by faith.

Within the novel, characters are often in conflict with one another which prevents their being able to come together to accomplish political work. As a result, the Latin community in the novel, and more specifically, the overall lives of the mothers and 
daughters are disadvantaged and in a state of poverty. The first step towards developing a political system which works for them is to establish solidarity between groups of people who are seemingly at odds with one another. Channette Romero describes latina literature as being concerned with finding similarities between groups of people as a foundation towards developing political alliances: “... women writers of color are increasingly moving from texts focused solely on the identities and issues affecting their specific cultural communities toward increased recognition of commonalities affecting multiple peoples in the Americas."'(7) So Far From God participates in a similar way by finding a basis of similar economic, and spiritual experiences as being the foundation of political solidarity. The characters in the novel experience and enact solidarity through a developed spiritual awareness, and a faith which inspires change; their solidarity produces a vision of politics in the novel that works to represent the needs of this specific community and to resist the already established structures of society which have oppressed and been harmful to the community of women in the novel.

The first instance of the novel's vision for a politics derived from solidarity is found within the first chapter. One of the main characters, La Loca, shows many signs of having spiritual and supernatural abilities, one of which is the ability to sense the pain that others have experienced. In her own words, she is able to smell when someone has undergone significant trauma. Such is the case of her father who had left her mother and his family. Though it is unclear what her father (Domingo) experienced during the time when he left his family, there were many rumors that he was living a somewhat dangerous life being involved in illicit activities like "running a gambling operation and living the high life," and also "that Domingo had married the woman who owned and ran 
the brothel..."(41) At some point during Domingo's familial absence, he experiences significant trauma which leads him to reevaluate his life and to bring him back to his family. Upon his return, Domingo seems to have changed as a person, but his wife Sofia is still unsure whether he is still the same man who left his family and has difficulty forgiving him for leaving. The only person in the family who is able to discern what Domingo has been through is La Loca and she is able to do so by her spiritual ability to sense what others are experiencing or have experienced without being told that they have been through it. The novel explains that Sofia found it odd that since Domingo had returned home, La Loca would continually approach him and sniff him. “'Jita,' Sofi asked her daughter one day when they were alone, 'what is it that you smell when you smell your father?, “'Mom,' La Loca said, 'I smell my dad. And he was in hell too... Mom, I been to hell. You never forget that smell. And my dad... he was there, too." Sofi then asks La Loca if she thinks that she ought to forgive her father for leaving his family for all of those years. La Loca responds: “Here we don't forgive, Mom,... only in hell do we learn to forgive and you got to die first, that's when we get to pluck out all the devils from our hearts that were put there when we were here. That's where we get rid of all the lies told to us. That's where we go to cry like rain. Mom, hell is where you go to see yourself. This dad, out there, sitting watching T.V., he was in hell a long time. He's like an onion, we will never know all of him - but he ain't afraid no more."(42-43) The first chapter opens up with a scene of solidarity between an absentee father and one of his daughters. Though the mother is hesitant to forgive him, the daughter senses that her father has been through an enormous amount of pain and trauma during the time when he 
left his family, and she explains that what he has experienced could be likened to being in hell.

The religious imagery employed during the scene between La Loca and Domingo presents the worst possible scenario or experience that a person may go through. In the beginning of the novel, La Loca herself passes away and is resurrected back to life which give her a spiritual insight and knowledge about both the afterlife but also our material experience. La loca explains that it is through traumatic experiences that people are able to have a change of heart to forgive others, to reevaluate themselves as individuals, and to return with a different perspective of others and themselves. Being that La Loca has had a similar spiritual experience to her father, and as a result of it has a gained a spiritual awareness of the suffering of others, she is able to both empathize with her father and forgive him for leaving the family. Domingo returns home as a changed man, a different person from what he was before he left his family. The solidarity between the two members of the family, because of a spiritual experience and awareness, presents the first instance of a vision of politics derived from solidarity and a common spiritual ground. Though not fully developed here, the type of solidarity between characters who would otherwise be hostile towards each other eventually grows into the very groundwork and structure of a political ideology and system which help the Tome community to recover from economic poverty and social hostilities.

The need for solidarity in developing political organizations and methods have long been analyzed and incorporated within communities and societies from second and third world countries. While many social issues grow out of very particular cases exclusive to certain locations and peoples, there is a history and tradition of women's 
workers finding ways to connect with one another nationally, and even transnationally, in order to find a common ground by which they could work together for the improvement of their working conditions and their communities. In her article "Feminist Solidarity Through Anticapitalist Struggles," Professor and activist Chandra Talpade Mohanty traces the various movements and organizations which have dedicated themselves to the rights and furtherance of women's rights as it pertains to working class women of color. Her concern is with forming strategic coalitions between women from various racial, cultural, and national backgrounds. Mohanty states: “A transnational feminist practice depends on building feminist solidarities across divisions of place, identity, class, work, belief and so on." Although the struggles of women in different nations and social classes are not the same or universal, Mohanty seeks to trace a common thread of the struggles which unite them and which could serve as a starting point or basis for building a vision of political and social justice which would be beneficial for many women in second and third world countries. She explains: "The differences and borders of each of our identities connect us to each other, more than they sever. So the enterprise here is to forge informed, self reflexive solidarities among ourselves." Thus Mohanty contends that solidarity is the basis upon which the resistance politics of working class women ought to be built upon. As a result of a global capitalist economy, women workers from working class communities are often exploited, underpaid, and underrepresented. Though Castillo's novel does not deal with the transnational struggles of women of color, she employs much of the same theory as Mohanty by presenting a vision of politics that are founded on the shared experiences, and struggles, of women workers and families living within the Tome community. The first episode between La Loca, her father, and Sofia is 
but the first instance where a solidarity formed on the basis of common spiritual experiences have brought together a family who was otherwise previously separated in their affections. Through his trauma, La Loca's father is presented as having experienced a type of healing that altered his perception of himself and of his family, bringing him back to his home.

\section{Part 2: Healing the Wound: Trauma, Healing, and Identity Formation}

Before a person can accomplish true faithful political action (as defined in this novel) that person must seek individual wholeness, which the novel connects to spiritual healing. According to Theresa Delgadillo twenty-first century LatinX fiction continues to be concerned with the place of women in spiritual and religious traditions, specifically as it relates to their positions as healing members of their communities. She states:"...in the present century, we see aheightened focus on the feminine divine and the female healer,saint, shaman, clairvoyant, or visionary in Latino/a fiction, even inthose fictions that feature repeated references to scripture, and evenin those fictions created by male authors."(611) So Far From God is heavily concerned with the traumas that are experienced by the main women characters at the hands of religious institutions, society, and capitalism. Central to the novel is how these women are able to overcome, and create a new framework of thought and political action which will be more beneficial to them and their community than the political, and religious systems that are currently in place. Therefore, before the novel presents its vision of an alternative political system grounded in spiritual principles, it first concerns itself with individual and communal healing which 
produces a shift in awareness. The insight which comes as a result of the healing process creates a vision of politics that aims to produce individual and communal wholeness. The most apparent example of healing within this novel deals with the miraculous healing of Caridad, one of Sofi's daughters who eventually becomes a curandera healer. ${ }^{3}$ At the beginning of the novel we learn that Caridad has had a very painful breakup with a man named Memo, and as result, she is known in her town as a woman who spends too much time in bars looking for attention from men. The narrator even goes on to state that some of the townspeople believed that Caridad went looking for the trouble she found herself in by leading a questionable lifestyle. Caridad is attacked and mutilated by some unknown force, a 'malogra' as stated in the novel, which is an evil spirit. She is left unrecognizable and on the brink of death. "What was left of Caridad had been brought home after three months in the hospital."(37) After some time at home, and after La Loca explains that she "prayed real hard," Caridad makes a miraculous recovery in which in an instant she is fully healed of her wounds and disfiguration. The novel explains:

"The three women huddled together went to the bedroom where Caridad was. Sofi stepped back when she saw, not what had been left of her daughter, half repaired by modern medical technology, tubes through throat, bandages over skin that was gone, surgery piecing together flesh that was once her daughter's breasts, but Caridad as she was before... Caridad was whole. There was nothing, nothing anyone could see wrong with her, except for the fact that she was feverish.”(38)

\footnotetext{
3 In her article "The Representation of Curanderismo in Selected Mexican American Works", Melissa Pabon defines Curanderismo as "a Mexican folk healing tradition with a history that is shared with other Latin American countries." Curanderismo differs from modern western medicine in its approach to healing the body by using "a variety of spiritual routines."
} 
Caridad's experience of supernatural healing launches her life into a new trajectory in which she begins training to become a Curandera healer, under the tutelage of Dona Felicia. Dona Felicia's healing practices and methods derived from a spiritual practice of healing the spirit and soul. Her own beliefs of spirituality are indicative of a faith practice founded upon a hybridity of beliefs: "Felicia was a non-believer of sorts and remained that way, suspicious of the religion that did not help the destitute all around her despite their devotion... she did develop faith, based not on an institution but on the bits and pieces of the souls and knowledge of the wise teachers that she met along the way."(61) In her healing practice, Felicia was able to recognize and separate between physical ailments, spiritual factors, and/or psychological illnesses. Her healing tradition was one which took into account all factors of a person's constitution (body, mind, soul, spirit).

The episode of Caridad's healing in the novel brings about a new way of perception and a new understanding for her character. Rather than focusing on her pain and trying to drown it out with liquor and superficial relationships with men, as she previously did, Caridad begins to shift her focus from herself to the healing of others in her community. The results is both a form of resistance to the dangerous and unjust social practices, and a reclamation of agency in a world where women do not often have it. In her article "Forms of Chicana Feminist Resistance: Hybrid Spirituality in Ana Castillo's 'So Far From God,"” Theresa Delgadillo traces the many spiritual and religious practices which form the hybrid spirituality present in this novel. In a section on the healing practices of Dona Felicia and Caridad she states: "Like her sister Loca, Caridad's curanderismo and spiritual life, combining attention to her own health with a vocation for healing others, allows her to challenge her own marginality and to assume agency."(908) 
In so doing, Caridad reclaims her sense of wholeness and identity after being so physically disfigured by la malogra. The image which we are presented with of a disfigurement so total that the character is not even recognizable, is so extensive that she not only spends three months in the hospital but that medical professionals are not able or capable of putting her back together. However, as a result of her sister's and her family's prayers, along with a divine healing occurrence, Caridad is restored, not only physically, but also psychologically and spiritually. The entire person is healed. Out of the trauma which she experiences is born a spiritual enlightenment and ability on her part. She begins to see herself and her community with new eyes, and she becomes a healing figure herself, often recognized as possessing supernatural healing capabilities.

Caridad's process of healing and her change into a curandera could be read as being representative of Gloria Anzaldua's theory of the Coyolxauhqui imperative. Anzaldua's theory suggests that traumas are necessary for a reframing of an individual's or a community's perceptions about reality and themselves. In experiencing trauma, a person is fragmented and dismembered, they become wounded at the level of the soul. In the process of healing the wound, a person is brought together, and an attempt is made at becoming whole. Anzaldua explains it this way: "Remember that while Coyolxauhqui in her dismembered state (depicted as a disk with topsy-turvy body parts) embodies fragmentation, she also symbolizes reconstruction in a new order. Her round disk (circle) represents the self's striving for wholeness and cohesiveness."(89, emphasis added) The Coyolxauhqui process which Anzaldua discusses is experienced firsthand by Caridad. The novel makes it a physical dismemberment which she experiences, but the inward process of introspection and a shift in perspective that results from both her wounds and 
her restoration are indicative of a healing process which goes beyond the physical and into the psychological and spiritual self. Anzaldua explains what happens during these traumatic experiences:

"Our habitual perspective changes when something jars us loose, when something traumatic... shocks us out of our habitual state. When we experience bodily and boundary violations, border shifts, and identity confusions, a flash of understanding may sear us, shocking us into a new way of reading the world... Although painful, this shift or shock is the first step in entering the territory of conocimientos/knowledge, insights the prevailing maintainers of the culture's laws would keep from you. Once recognized, these understandings render identity malleable, allowing greater freedom in constructing identity.”(86)

For Anzaldua the wound is essential for altering our understanding of our own identities and the reality around us. A flash of understanding results from our struggles with our wounds, and this is precisely what occurs with Caridad as she spends months in the hospital and then in her home wounded beyond any mainstream medicinal hope. However, she goes on to make a full recovery, she is able to gain an insight into herself and her reality that she was previously unaware of. Her heart is changed and she becomes both a forgiving individual and also a clairvoyant curandera. The novel states of Caridad's inner qualities:

"It was a funny thing because you might figure that after what happened to her, not only with Memo, but especially because of that nightmarish night in Caridad's life, she might have become an embittered woman, who hated men for having served little purpose in her life but to bring misery and shame. But she didn't. 
Caridad was incapable of hating anyone or anything, which is why dona Felicia had elected her heiress to her healing legacy. Hating came quite easy in this life of injustices, dona Felicia figured, but having an abundant heart took the kind of resiliency that a curandera required."(77)

This life changing experience that Caridad endured at the hands of the Malogra sent her into a trajectory of change, healing, insight, and complete identity transformation. Her wound and her trauma were the basis for her miraculous recovery from both a physical injury, and a spiritually unaware state of being. Caridad becomes, in her own way, a holy figure. Caridad's healing process and the novel's representation of what she becomes presents a characteristic example of how the politics in this novel grows out of a healing process and experience. Before the community of Tome is able to come together to make a significant change in the lives of its members, they must first engage in a healing process in which they shift their thoughts and expectations for themselves and their families.

\section{Part 3: Spiritual Activism: Politics Inspired by Faith}

The Tome community begins to change as a result of Sofia's experiences with her daughters' struggles. Sofi's own awareness and spiritual life is changed after witnessing what her daughters have gone through, and by incorporating the spiritual lessons they have learned into her own vision of politics. Sofi begins to fulfill her political vision of becoming the first mayor of her Tome community and her politics are based on her deceased daughter's Esperanza's belief that political action and societal change ought to 
be approached from a perspective of faith. This faith is not necessarily a doubtless belief in canonical sacred texts or accepting a pre-

ordained plan by God, but rather Castillo suggests that a faith that can lead to political action is one that believes in the possibility for individual and community change. This type of political work and activism also becomes a means of personal and community healing. The type of political vision which Sofi puts into practice is one which serves to empower the latina women in her community and which resists the dominant and harmful practices of capitalism upon latin women workers. Sofi announces to one of her friends, La Comadre, that she intends to run for the mayor of Tome and that her purpose in doing so is that "I'm sure willing to work for community improvement!" The comadre does not at first think that this is a good idea, or a realistic idea on Sofi's part and she responds with some reservations and doubts: "Community improvement? And what does that mean? You are starting to sound like your daughter, the revolutionary!... Anyway, there has never been no mayor of Tome!" La comadre even tells Sofi that all of these political ideas are arising from her overactive imagination. Sofi responds by stating: "It's not 'imagination' that I've always had, comadre, it's faith! Faith has kept me going,... But you... you have always been a... a... A conformist!' La comadre, offended by Sofi's accusation asks what Sofi means by saying that she is a conformist, a conformist to what? Sofi responds: “That's what my 'jita la Esperanza used to call people who just didn't give a damn about nothing! And what's why, she said, we all go on living so poor and forgotten!'(138-139) At this point the two friends begin to argue and discuss how unfortunate their economic conditions have become as the generations have passed and they both agree that something must be done in order to reverse the poverty and 
economic injustices which have occurred for too long in their Tome community, specifically as it relates to their women friends and how it has affected their families. During this episode we become aware of the motivation of Sofi's politics, as she is both inspired by her deceased daughters' memory as an activist, but also her political vision as being based on having faith, as she states. It is this faith which has kept her going and which has given her a purpose in wanting to bring about a change.

During the conversation between Sofi and La Comadre, we are able to deduct that when she speaks about faith, she is not necessarily meaning a faith in God, but instead a faith in her and her community's ability to effect change. The opposing stance of not having faith, according to Sofi and her daughter Esperanza, is to be a conformist. Conformists are those "people who just [don't] give a damn about nothing! And that's why we all go on living so poor and forgotten!" Sofi equates not having faith and being a conformist with poverty. She is here implying that they as a community are at least partially responsible for the economic and social conditions which they have found themselves in. The economic conditions that they find themselves in is one where their fortunes and lands are slowly dwindling away and being taken from them at the hands of foreign investors and capitalist corporate production. La Comadre tells Sofi: "Well, what ARE we supposed to do, comadre? All we have ever known is this life, living off our land, that just gets mas smaller y smaller. You know that my familia once had three hundred acres to farm and now all I got left of my father's hard work - and his father's and his father's - is casi nada, just a measly ten acres now, nomas, comadre! Barely enough for my family to live on!" The narrator goes on to say that "there were a lot of outsiders moving in, buying up land that had belonged to original families, who were 
being forced to give it up because they just couldn't live off of it no more, and the taxes were too high,..."(139) Here we see how the families in the Tome community are being affected by not being able to produce a sufficient amount of revenue. They are, over many years, losing a significant amount of their family owned lands, and these lands are being purchased by outsiders. Out of this type of economic pressure, Sofi decides to put together an organization of women's laborers who are able to find new and creative ways to work together and produce more than they would be able to if they just worked alone.

Many of the women in the Tome community were in a similar situation to la Comadre and Sofi, and out of this shared economic experience and state, they come together in solidarity to create Los Ganados Y Lana Cooperative which was "a sheepgrazing wool-weaving enterprise." This small wool-weaving cooperative was started by Sofi and eleven other women and "eventually, the business created and sustained the livelihoods of more than two dozen women. As cooperative owners of their woolweaving business they had paying jobs they could count on and were proud of..." What started with this cooperative labor amongst these latina women eventually grew into a movement that encompassed dozens of women all around Tome working in different areas of production, all of which was "inspired by the diligence, ingenuity, and communal spirit of Sofi's vecinos,...”(148, emphasis added) This communal sense of solidarity between these women workers began and was inspired by Sofi's idea that faith is central to societal and economic change. Where she believed that they had been conformists before, she created a political vision and ideology that incorporated spiritual beliefs and factors into their daily, political and agriculturally productive practices. Sofi's political inspiration and her motivation to bring about a change in her community from the 
perspective of conformism to a faith-based, spiritual political action calls upon Gloria Anzaldua's own theories of Spiritual Activism. This type of personal and social activism is one which centers around the cultural and psychic wounds which have been experienced by cultures who have been subject to the injustices of racism, sexism, colonialism, and even capitalism. Anzaldua describes the preliminary process of spiritual activism as: "Our task has always been to heal the personal and group heridas of body, mind, spirit. We must repair the damage that we have perpetuated on members of our own group, that men have rendered to women and women to men, that adults have done to children, that all groups have done to other groups."(89) Out of this introspection and an intent to heal our personal and communal wounds is born a vision of spiritual action which becomes political in its accomplishments. Anzaldua continues: “... you have to plunge your hands into the mess, plunge your hands en la masa, into embodied practical material spiritual political acts. This politics of embodied spiritualities (that I term 'conocimiento') es nuestro legado.”(90) This novel reevaluates the position which the spiritual beliefs and practices of individuals have on their political actions. The novel itself belongs to a genre of literature which is known as resistance literature as it challenges the more dominant religious and political ideologies which have long produced adverse and negative effects on latina and other minority communities. Through So Far From God, Castillo is able to envision and form a political system and structure that represents the needs and values of underprivileged latina communities, and the very basis of this political system is a solidarity based on faith and a spiritual perception of the realities around us. Rather than being only focused on the material world which surrounds us, and the many negative consequences upon our material 
realities resulting from economic and political injustices, this novel digs into the very soul of its characters to see how their spiritual beliefs are able to shape and construct the material world in which they live.

While Ana Castillo's So Far From God focuses on the spiritual experiences of a family of women, and how their spiritual experiences are translated into a vision of political action, Demetria Martinez's Mother Tongue focuses primarily on the life of one woman, Mary, and her search for a whole identity. Through her studies of various religious and spiritual practices and faiths she is able to find a spirituality which is representative of Anzaldua's Spiritual Activism. Mother Tongue's method of individual healing is more concerned with narrative and storytelling as a way to heal individual wounds and to process the many traumas experienced by its main character. Through her re-telling of her own autobiography to her son, Mary participates in both introspection, and also confession as she reveals her darkest moments to her son. By telling these secrets through confession, Mary is able to let things go, to accept the things which cannot be changed, and to heal from her traumas and wounds which have kept her from being present in her life. Ultimately, Mary engages in a political work that is also based on solidarity with the poor and with other mothers who have experienced the loss that she herself has endured as she becomes the Mother of the Disappeared.

\section{Chapter 2}

\section{Section 1 Demetria Martinez's Mother Tongue}


Demetria Martinez's Mother Tongue follows the life of nineteen year old Mary as she is tasked with caring for and transporting a Salvadoran Refugee during the Sanctuary Movement of the 1980's and 1990's. ${ }^{4}$ The novel highlights the injustices occurring in El Salvador during the Salvadoran Civil War, but also it focuses on the systemic injustices against women both in Latin American countries, and in the United States. As a result of her experience falling in love and being left by the Salvadoran refugee, Jose Luis, Mary's spiritual and political consciousness evolves from a personal, self-serving religious practice, to one which concerns itself with the needs and representation of women who have suffered trauma as a result of traditional, and oppressive, religious and political systems both in South America and in the United States. As Mary wrestles with various paradoxical religious and spiritual beliefs, she becomes more aware of the need for social justice and reform. Through the avenue of storytelling, as she writes down a narrative of her life for her son, she is able to better understand and make sense of the traumatic experiences in her life, and as a result, to find some semblance of wholeness from an otherwise fractured sense of identity. Out of her construction of a narrative of her life, she becomes concerned with not only her own individual healing, but also a sense of solidarity with the many women who have also suffered similar, and often worse fates than she has.

\section{Part 1: Hybrid Spirituality: Mary's Evolving Spiritual Identity}

\footnotetext{
4 In her book On Latinidad, Marta Caminero-Santangelo explains Demetria Martinez's own involvements with the Sanctuary movement and how that experience informed and inspired Mother tongue. Santangelo describes the Sanctuary movement as being composed of several Christian Church groups who formed an underground movement that transported fugitives from Latin America into the United States by offering them sanctuary in their churches.
} 
Throughout much of the novel readers witness Mary's spiritual growth and evolution from a spiritual practice and belief that is mostly focused on the self to one which goes beyond the individual and connects the spiritual life to a socio-political cause. In her search for meaning and a sense of identity, Mary struggles and wrestles with popular religious beliefs about the place of goodness and evil in the world. Coming from an otherwise Catholic religious background, Mary also delves into other religious, and non-religious texts, in order to find alternative ways of viewing the world and making meaning out of traumatic experiences which she, and other immigrant and latin American communities are experiencing in the novel.

During an event in which Jose Luis travels between Church meetings to tell his testimony as a Salvadoran refugee, Mary struggles to make sense of why bad things happen to good people. She states: "It was really awful hearing Jose Luis last night at the Quakers'. I know shit like that happens in the world, but why good people get the bulk of it is beyond me."(37) Mary struggles to reconcile her religious beliefs as taught to her by religious institutions and the state of the world as it is in relation to the immigrant experience. For Mary, the religious philosophy which she was raised with, the Catholic tradition, did not satisfy her questions and concerns with her own individual identity and the current socio-political climate. As a result, Mary spends much of the novel seeking, through various religious sacred texts, answers to her philosophical and religious questions. She explains: "While Jose Luis was copying the works of revolutionaries, I was pouring over Eastern Mystical texts, discovering the meaning of life, for the moment at least, in gods incarnated as elephants and monkeys and many-breasted goddesses.'(47, Emphasis added) Mary's approach to a spiritual tradition that is effective in answering 
life's difficult questions, and in revealing meaningful aspects of the lived experience, is similar to what Christina Delgadillo terms a 'hybrid spirituality' in which various religious and spiritual practices are brought together to create a framework for understanding and practicing alternative forms of spirituality.

As Mary navigates through her own journey of spiritual identity formation, her aunt Soledad is careful to instruct her in a spiritual practice which incorporates social action. Soledad warns Mary against a pursuit of spirituality that is only concerned with the self. She likens Mary's spiritual beliefs with the New Age movement and instructs her to keep in mind that our spiritual beliefs ought to produce social action and justice. Soledad tells Mary: "Now I know you wear that crystal around your neck. If you ask me, some of that New Age Santa Fe stuff can be as bad as drugs. People start out trying to cure a cold and next thing you know, instead of taking garlic and lemon water, they've hired someone to 'channel the voice of Visigoth. Before you go knocking on heaven's door, it's best to look for cures a little closer to home. Roots, seeds, bark, oils, flowers, etc." Soledad here warns Mary that if a person is not careful, their spiritual explorations can disconnect them from the real world. She tells Mary to make sure she stays 'close to home'. She continues: “And since I am your godmother, I want to keep you on the straight and narrow, what with all that New Age out there. Beware of fundamentalists, even the ones with crystals, hippie sandals, and trust funds. Now that's not to disrespect true spiritual seekers. After all, some of those Santa Feans have Free Tibet bumper stickers on their vans. So if turning inwards helps them turn outward to do something useful in this vale of tears, then maybe God works even in the New Age. But I know you're not into politics (yet, ha ha)."(112) Here Soledad criticizes the New Age 
movement as being too focused on the self and other aspects of spirituality that do not have a social/political concern. However, she explains that if turning inwards to find a kind of spiritual enlightenment helps people to turn outwards to do political work, then God is truly working even in those movements.

For Soledad, it is clear that a valid, and true form of spiritual practice, and tradition, must contain a social and political factor. Soledad's own spiritual practice was concerned with the welfare of the immigrant and refugee population in her town. She was concerned with battling the injustices that affected the material bodies of individuals by the hands of oppressive government regimes. In her article "Embodying Latina Salvation" Channette Romero discusses how Mother Tongue addresses the violence and traumas experienced by refugees on their material bodies, and how this experience is part of a larger global injustice that is present across national borders. By discussing the roots of the Liberation Theology movement, Romero explains that the Mother Tongue "text reconnects the material body to the spiritual." In order to return to the roots of older spiritual and religious traditions that are effective in bringing about social change, Mother Tongue is concerned with the "recognition of the suffering experienced by the material body and its inextricable connection to spiritual suffering."'(185) Romero hereby makes a clear connection between our spiritual experiences and our material bodies. When the bodies of refugees suffer as a result of political injustice, this affects the spiritual lives, beliefs, and identity of those involved. As a result of this, Soledad is careful, and adamant to be involved in the liberation of oppressed refugee communities. Soledad's own spiritual work as an herbal healer is inspired by her own traumas and painful experiences from social institutions and relations. "In her life, with her husbands, divorces, her 
breaking the rules of the church, in all these experiences and more, Soledad had seen the two faces of God. So she was not about to tell me not to live dangerously... She was a healer precisely because she had suffered and savored the faces of God, the dark and the light. And every remedio, she said, has elements of both, of the sickness and the cure."(113) Out of these painful experiences, Soledad became aware of her responsibility to work towards affecting a change in her immediate community. Out of the pain experienced by her material body, Soledad was able to become spiritually aware and to become inspired to heal the societal wounds which she could see around her. Thus, the novel itself aspires to present a hybrid spiritual practice which concerns itself with sociopolitical change as the result of these inward spiritual beliefs. It contends that our material reality ought to be transformed by our inward spiritual beliefs. Out of these beliefs are born actions which are able to affect, and change, the material world and its structures of oppressive order.

\section{Part 2: Narrative As A Healing Practice}

As the novel takes readers through Mary's spiritual and political transformation, it does so by highlighting how narrative, and storytelling, have been the basis for Mary's spiritual and political identity formation. The novel suggests that it is through narrative and writing that Mary wrestles with her trauma, comes to make sense of it, and becomes aware of the power of storytelling to disrupt and resist oppressive discourse. Using narrative as a form of making sense of trauma, and becoming more politically conscious results in what Gloria Anzaldúa calls 'conocimiento'. In writing and telling her story of 
past trauma and her involvement in the Sanctuary movement, Mary both begins to change her perspective on issues relating to social justice, but also, the novel serves as a relevant example of how narrative works to affect and inspire social change. As readers become invested in the narrative itself, they also open themselves up to new ways of knowing and understanding that may previously not have been present in their political and social ideas. These new ways of knowing are what Anzaldua calls 'conocimiento', which she connects to the process of creating narrative: "Writing is a process of discovery and perception that produces knowledge and conocimiento (insight). I am often driven by the impulse to write something down, by the desire and urgency to communicate, to make meaning, to make sense of things, to create myself through this knowledge-producing act"(1, Light in the Dark) Mother Tongue narrates this same process of writing as a means to understanding the self, and finding new ways to solve age-old problems which pertain to injustice and systemic violence.

The use of narrative as a knowledge producing act is apparent in the lives of both Jose Luis, who writes poetry that is resistant to oppression, and in Mary's own autobiographical writing. As Mary writes about Jose Luis throughout the novel, she repeatedly makes reference to the texts he reads and what he writes in his journal. She says: "It became obvious to me that poetry was his life. In the throes of apparently meaningless suffering, he lit it and smoked it and passed the sacred pipe to his friends until a new vision came to them about their earthly mission."(43) For Jose Luis, poetry was a revolutionary act, he wrote not only to represent his experiences and those of other Salvadorans in similar situations, but to envision ways of changing his and his community's material circumstances. Poetry, and writing, becomes a sacred act in itself, 
as the novel connects itself with other sacred religious texts which have themselves inspired people throughout history to change their circumstances and to stand against injustice. While Jose Luis's poetry has revolutionary, and resistant characteristics, Mary's own writing differs from his in that she is more concerned with writing about her inward thoughts, feelings, and experiences. Throughout the novel she is usually not very concerned with bringing about social change, or writing in order to achieve that. Her writing is more an act of self-realization, and processing trauma in order to heal the spirit and the soul. She employs the use of confession as a narrative technique which is able to accomplish those aims. Her confession comes as she addresses her son, and her struggle to be honest with him about his father Jose Luis. Mary writes, "Someday I have to tell my son the story of his room and the spirits that dwell there. But first, I must tell myself the rest of the story, chew on it like Osha root, sweat it out. What I can't remember, I will invent, offer up my tales, for those who were not granted time enough to recall, to mend. My son is cursed with a mother who makes up stories, a liar, blessed with a mother who is a storyteller...”(150) For Mary, storytelling has helped her to put the pieces together from her life. Having experienced significant trauma at the hands of men throughout her life, both Jose Luis, and sexual abuse by her neighbor as a child, writing down her life's story has helped her to find some semblance of wholeness out of the scattered and fractured pieces which are her life. As she struggles to find meaning and purpose out of these painful experiences, as she writes, she begins to gain insight (conocimiento) of how to turn painful experiences into something which can be used towards healing not only herself, but other women and mothers who have experienced trauma as well. Channette Romero explains that Mary's experiences are not only her own, or specific to her life, but 
that they are part of a larger narrative of social injustices: "The issue, the text suggests, is that the traumas of the refugee body and the female body are connected through larger global injustice."(Romero, 185 Embodying Latina Salvation) The novel highlights these injustices as being woven into popular discourse and various belief systems throughout latin american, and chicana culture.

The process of writing and creating narrative becomes in itself a spiritual, and political work for Mary, Jose Luis, and for Demetria Martinez through her novel. Though Mary's autobiographical writing may seem primarily to be concerned with herself, and not so much with effecting political change, the very act of writing and seeking to understand her own traumas becomes a political action. In her book Calling the Soul Back: Embodied Spirituality in ChicanX Christina Garcia Lopez conducts a study on how narrative is used to heal the body of 'susto', a term which Anzaldua describes as when the spirit leaves the body as a result of trauma. Lopez contends that our political and social anxieties in this day and age ought to be reevaluated by taking into account our spiritual selves as being central to our concern for political justice. Lopez describes stories as being medicinal and conducive to restorative work: "... the writer is conceptualized as healer, able to draw on intimate knowledge of the community, including its history and its wounds, and to powerfully acknowledge that which has been silenced, creating a space where suffering can be heard and shared and the self can be reclaimed." Much of Mother Tongue involves Mary's own journey towards reclaiming herself and constructing her own identity which has been shaped by the trauma which she has experienced. Through the writing process, Mary engages in meaning making, restorative work which eventually leads to a political vision that is inspired by her 
spiritual work. Lopez continues: "For those who carry in their bodies, minds, and spirits the visceral pain of knowing that their own story is 'viewed as unworthy of description' or attention, such narrative spaces can be sacred,...”(10) Through its use of narrative techniques which involve confession, inner healing and restorative work, Demetria Martinez's novel posits itself as an alternative sacred text which disrupts long established forms of oppression as it relates to traditional religious knowledge and practice. In so doing, Martinez's novel questions the authority of sacred traditions - and sacred texts and puts itself forward as a sacred text for modern times. Jacqueline Hidalgo explains that modes of authorization of sacred texts are largely beneficial to a specific group of people, while also diminishing the validity of other sacred forms of knowledge:

"Academic fields at large, but perhaps biblical studies especially, are circumscribed by a certain politics of reading: the "acceptable" canon of scholarly sources within any particular field, the authority that adheres to the reading of certain texts and not others, and the practices of authorization that surround and enable only certain ways of reading those texts."(121)

\section{Conclusion:}

Ana Castillo's and Demetria Martinez's novels participate in and situate themselves in the LatinX field of literary fiction as resistance literature. Through the use of fiction, and storytelling, these two novels envision new ways of collaborative work that are based on solidarity and the spiritual beliefs of latina communities. Borrowing from various religious traditions, they create a hybrid spirituality that encompasses seemingly paradoxical beliefs in a visionary process which highlights the importance of 
religious tolerance, and alternative political ideologies which resists dominant capitalist practices. Through their studies of sacred texts, Church history, and religious traditions, these texts both question the efficacy of religion and spirituality in effecting positive changes for oppressed communities of color. They criticize religious traditions which have been used in oppressive ways towards women and minorities, and they envision new ways that religion and spirituality could be used for the inspiration and political motivations necessary to advance the welfare and equality of these communities. In their own way these two novels set themselves up as modern, alternative, sacred texts which are written primarily with LatinX communities in mind. Borrowing from other religious traditions, Demetria Martinez and Ana Castillo's novels propagate a unique vision of spirituality that is inextricably linked to the need for political action and social change. 
Works Cited

Anzaldua, Gloria. Light in the Dark: Rewriting Identity, Spirituality, Reality. The Gloria Anzaldua Literary Trust.

Anzaldua, Gloria. Borderlands La Frontera: The New Mestiza. San Francisco, aunt lute books, 1999.

Ashcroft, Bill., and Helen Tiffin, editors. "The Sacred." The Postcolonial Studies Reader. New York, Routledge, $2006,517-518$

Caminero-Santangelo, Marta. On Latinidad: U.S. Latino Literature and the Construction of Ethnicity. Gainesville, University Press of Florida, 2007.

Castillo, Ana. So Far From God. New York, W.W. Norton \& Company, Inc., 1993.

Delgadillo, Theresa. "The Criticality of Latino/a Fiction in the Twenty-First Century." American Literary History, vol. 23, no. 3, Fall 2011, pp. 600-624.

Delgadillo, Theresa. "Forms of Chicana Feminist Resistance: Hybrid Spirituality in Ana Castillo's So Far From God." Modern Fiction Studies, vol. 44, no. 4, Winter 1998, p. 888.

Firmat, Gustavo Perez. Tongue Ties: Logo-Eroticism in Anglo-Hispanic Writing. Palgrave Macmillan, 2003.

Hidalgo, Jacqueline M. "The Politics of Reading: US Latinas, Biblical Studies, and Retrofitted Memory in Demetria Martínez's Mother Tongue." Journal of Feminist Studies in Religion (Indiana University Press), vol. 29, no. 2, Fall 2013

Lopez, Christina Garcia. Calling the Soul Back: Embodied Spirituality in Chicanx Narrative. Tucson, University of Arizona Press, 2019.

Martinez, Demetria. Mother Tongue. New York City, One World Books, 1994.

Mohanty, Chandra Talpade. "Feminist Solidarity Through Anticapitalist Struggles." The Post-Colonial Studies Reader, edited by Bill Ashcroft, Gareth Griffiths, Helen Tiffin, Routledge, 2006, 485-490.

Pabón, Melissa, and Héctor Pérez. "The Representation of Curanderismo in Selected Mexican American Works." Journal of Hispanic Higher Education, vol. 6, no. 3, July 2007, pp. 257-271.

Romero, Channette. Activism And The American Novel: Religion And Resistance In Fiction By Women of Color. Virginia, University of Virginia Press, 2012. 
Romero, Channette. "Embodying Latina Salvation: Demetria Martinez's 'Mother Tongue.”" English Language Notes, vol. 44, no. 1, Spring 2006. 